\title{
Role of school teachers in identifying attention deficit hyperactivity disorder among primary school children in Mansoura, Egypt
}

N.J. Awadalla ${ }^{1,2}$, O.F. Ali ${ }^{1}$, S. Elshaer ${ }^{1}$ and M. Eissa ${ }^{1}$

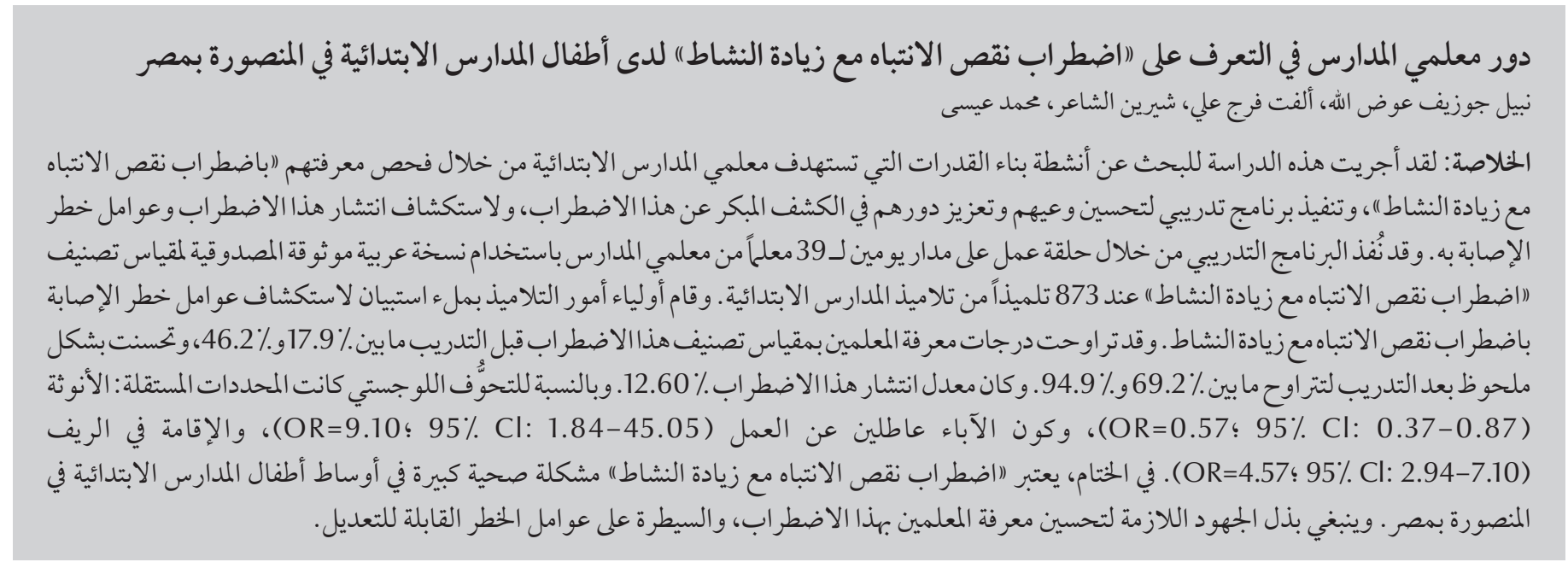

ABSTRACT There is a knowledge gap in primary school teachers that affects their ability to detect attention deficit hyperactivity disorder (ADHD). This study measured primary school teachers' knowledge about ADHD, and implemented a training programme to improve early detection of ADHD. The prevalence and risk factors of ADHD were also studied. The training programme was implemented through a 2-day workshop for 39 primary school teachers who completed a validated Arabic version of the ADHD Rating Scale for 873 primary school children. The children's parents completed the questionnaire to explore ADHD risk factors. The teachers' pre-training knowledge scores of ADHD ranged from 17.9 to 46.2\%. Post-training, their scores improved significantly to $69.2-94.9 \%$. Prevalence rate of ADHD was $12.60 \%$. On logistic regression, independent predictors of ADHD were female gender, unemployed fathers and rural residence. In conclusion, ADHD is a significant health problem among primary school children in Mansoura, Egypt. Efforts should be made to improve teachers' knowledge about ADHD and control modifiable risk factors.

Rôle des enseignants dans l'identification du trouble de déficit de l'attention avec hyperactivité parmi les élèves du primaire à Mansoura, Égypte

RÉSUMÉ Il existe certaines lacunes en matière de connaissances des enseignants du primaire qui affecte leur capacité à détecter le trouble de déficit de l'attention avec hyperactivité (TDHA). La présente étude a permis de mesurer les connaissances de ces enseignants à cet égard et de mettre en place un programme de formation visant à améliorer le dépistage précoce du TDAH. La prévalence et les facteurs de risque de ce trouble ont par ailleurs été examinés. Le programme de formation a été mis en place sous la forme d'un atelier de deux jours destiné à 39 enseignants du primaire qui ont réalisé une évaluation du TDAH pour 873 élèves du primaire en utilisant une version arabe validée de l'échelle. Les parents des élèves ont rempli un questionnaire visant à déterminer les facteurs de risque du TDAH. Les scores à l'échelle d'évaluation du TDAH portant sur la connaissance des enseignants avant la formation allaient de 17,9\% à 46,2\%, et affichaient une nette amélioration après formation (69,2\% à 94,9\%). Le taux de prévalence du TDAH était de 12,60\%. La régression logistique a révélé que les variables indépendantes étaient l'appartenance au sexe féminin, le chômage du père et la résidence en milieu rural. En conclusion, le TDAH représente un problème de santé important parmi les élèves du primaire à Mansoura, en Égypte. Des efforts doivent être déployés pour améliorer les connaissances des enseignants sur le TDAH et contrôler les facteurs de risque modifiables.

'Community Medicine Department, College of Medicine, Mansoura University, Mansoura, Egypt (Correspondence to: N.J. Awadalla: njgirgis@yahoo.co.uk). ${ }^{2}$ Family and Community Medicine Department, College of Medicine, King Khalid University, Abha, Saudi Arabia.

Received: 11/5/2015, Accepted: 3/7/2016 


\section{Introduction}

During the past few decades, many reports have raised concerns about the issue of childhood attention deficit hyperactivity disorder (ADHD), which may affect all aspects of a child's life. It is a chronic condition that includes high levels of impulsivity, hyperactivity and inattention problems (1). ADHD is one of the leading causes of academic underachievement in school, as well as disruptive behaviour (2) and affects $3-5 \%$ of school-age children (3). There is strong evidence that symptoms of ADHD persist into adulthood for 30 $70 \%$ of children with the disorder (4).

The aetiology of $\mathrm{ADHD}$ is multifactorial with a strong genetic component. Nongenetic risk factors are thought to play a role in the prenatal and early postnatal periods, when the developing brain is particularly vulnerable to injury (5). Identifying and controlling the modifiable risk factors of ADHD is of public health importance given the substantial burden on the quality of life of affected children and their families; the large number of children treated with stimulant medication; and the strain on medical, educational and social resources (6). Identifying risk factors for $\mathrm{ADHD}$ diagnosis, can inform screening, monitoring and treatment by mental health professionals, paediatricians and preschool and school staff at an age when these efforts may be maximally effective (7).

In Egypt, primary schools have children from all socioeconomic backgrounds and health concerns can potentially be addressed. Contact between teachers and primary schoolchildren is close, therefore, teachers are often aware of individual student life circumstances (Directorate of Education, Mansoura, unpublished data, 2011). Teachers are able to observe children at a developmental stage when attitudes, behaviour, health literacy and life skills that affect future health are forming (8). Thus, through adequate education and proper training, teachers can play an important role in early detection and management of ADHD (9).

There is a knowledge gap that affects the ability of Egyptian primary school teachers to detect ADHD early and manage it appropriately. The present study addressed 3 objectives: (1) to assess teachers' current knowledge about different aspects of ADHD; (2) to improve teachers' capacity for identifying key aspects and management of ADHD in the classroom through intervention programmes; and (3) to assess the screening prevalence rate of $\mathrm{ADHD}$ reported by teachers while identifying the risk factors for $\mathrm{ADHD}$.

\section{Methods}

\section{Study setting}

The study was carried out in 4 primary schools in Mansoura District, Dakahlia Governorate in the Delta Region of Egypt. The district primary school student population is $\sim 100000$.

\section{Study design and sampling}

We conducted a descriptive crosssectional study on a representative sample of students randomly selected from 4 primary schools in Mansoura District using a multistage stratified cluster sample. The sample size was calculated using the World Health Organization manual for sample size determination in health studies (10). With anticipated prevalence of ADHD among primary schoolchildren of $7 \%$ (11) and level of absolute precision of $2 \%$ at $95 \%$ confidence, the minimal sample size required for the study was calculated as 625 students. To account for cluster sampling error and possible non-response, a total sample of 850 students was targeted for inclusion. The target population included boys and girls who were in primary school grades $2-6$. We randomly selected by lottery 3 public schools ( 2 urban and 1 rural) and 1 private school with a total of 4064 students. Stratified cluster random sampling was used according to 5 grades of primary education, with a final sample size of 873 . Data were collected over 2 academic years from 2011 to 2013.

\section{Study tools \\ Teachers' training workshop}

Thirty-nine principal teachers who usually have a long contact time with the students from the 4 selected schools were included in the workshop. The workshop objectives were: assessment of baseline knowledge about ADHD; highlighting the importance and burden of ADHD; improving the capacity of school teachers for early detection and classroom management of ADHD; and evaluation of the acquired knowledge at the end of training. The training was implemented through a 2-day workshop in the school library, with each daily session lasting for 2 hours. Training consisted of presentations with audiovisual aids focused on definition of ADHD, symptoms, how to manage students with ADHD in the classroom, role of teachers in early detection of ADHD, and referral to specialized care providers. Also, hand-outs about ADHD detection, risk factors and management were distributed.

A self-administered questionnaire was used to evaluate pre- and post-training knowledge. The questionnaire was compiled by the researchers and based on the study of Kos (11). The content of the questionnaire was validated by $\mathrm{ADHD}$ experts rating each item. Content validity index for different scoring items was 0.97 . Reliability was assessed by measuring internal consistency using Cronbach's test and it was found to be acceptable (0.79). The questionnaire comprised items related to the demographic characteristics of the teachers as well as 20 items assessing teachers' knowledge of ADHD. Each item was assessed on a 2-point scale (incorrect response and don't know $=0$, correct response $=1$ ). The questionnaire items were as follows: nature of disease (1 
item), age of onset (1 item), sex prevalence (1 item), disease course (1 item), symptoms (7 items), risk factors (4 items), aggravating factors (4 items) and management ( 1 item). The questionnaire had a maximum score of 20 . Adequate knowledge was considered when the teachers achieved $65 \%$ of the total score.

\section{History and sociodemographic crite- ria of school students}

Parents of school children were asked to respond to a self-administered questionnaire about their children's age, sex, grade, residence, education, and work of parents. The questionnaire also included the possible risk factors for ADHD during antenatal, natal, infantile and early childhood periods. These risk factors were developed after extensive review of the literature $(1,5,8,9,12)$. Social score and socioeconomic level of the family were calculated according to the Fahmy and El-Sherbini scoring system (13).

\section{Screening for ADHD}

We used the validated Arabic version of the ADHD Rating Scale (14). It was a translated and linguistically standardized version of the original ADHD Rating Scale (15) and was previously used in Saudi Arabia. It contained 14 items; each of which was measured using a 4-point Likert scale (0-3) describing ADHD symptoms. The rating scale scored the symptoms as: (0) "for not at all", (1) "for just little", (2) "for much" and (3) "forvery much". The total scores at the cut-off points for male (23.5) and female (22.5) participants were used for detection of ADHD with $74.2 \%$ sensitivity and $77.3 \%$ specificity (14). The internal consistency using Cronbach's of the $\mathrm{ADHD}$ questionnaire, inattention subscale and hyperactivity subscale was $0.85,0.81$ and 0.73 , respectively (14). The teachers were given intense training on the $\mathrm{ADHD}$ questionnaire and how to use it for observation and identification of vulnerable students. They were given sufficient time, an academic year, to observe their students and complete the scoring for each student.

\section{Statistical analysis}

We used SPSS version 18.0 for statistical analysis. Descriptive statistics were presented as number and percentage for categorical data and mean and standard deviation (SD) for continuous data. 2 tests were used for the association between categorical variables. Quantitative data were examined for normality distribution using the Kolmogorov-Smirnov test and the results were significant for variables related to teachers' ADHD knowledge scores $(\mathrm{P}<0.05)$, indicating a non-normal distribution. The McNemar test and Wilcoxon rank test were used to compare pre- and post-training knowledge scores. Significant factors predicting ADHD on univariate analysis were entered into multivariate logistic regression analysis to establish the independent predictors of ADHD. Odds ratios (ORs) and 95\% confidence intervals (CIs) were calculated. $\mathrm{P}<0.05$ was considered statistically significant.

\section{Ethical considerations}

The study was approved by the Research Ethical Committee of Mansoura University, Education Directorate of Mansoura District and the administration of the schools. Signed informed consent was obtained from the children's parents. Appropriate referral was done for any suspected case.

\section{Results}

According to Table 1, less than half of the teachers correctly responded to questions about disease symptoms and gender-based prevalence. Also, about one third of them gave correct responses to disease nature and causes. More or less than a quarter correctly responded to age of onset, channels of treatment lines and life progress of disease. The overall results of response to the questions about sources of $\mathrm{ADHD}$ information revealed that $\sim 31 \%$ of the teachers had no information about ADHD, and most of them gained their knowledge about ADHD from television (26\%), books and magazines (20\%) and friends and the internet (10\%) (data not shown).

Post-training assessment revealed a highly significant improvement in the different aspects of disease knowledge (Table 1). The post-training correct responses ranged from $69.2 \%$ for disease progress to $94.9 \%$ for some symptoms and factors that increase symptoms. Additionally, the average post-training scores were significantly higher than the corresponding pre-training scores for all knowledge aspects (Table 2).

Recently graduated teachers seemed to be more informed about $\mathrm{ADHD}$ as adequate knowledge was significantly higher among teachers with 1-4 years' experience than those with 5-10 years and > 10 years experience. In contrast, age, sex, school type and educational level were not significantly associated with pre-training knowledge level (Table 3).

Eight hundred and seventy-three primary schoolchildren were observed for ADHD by trained teachers. Their sociodemographic features are listed in Table 4. They were nearly equally distributed in gender. Most of them were aged 9-11 years and were from urban areas. Most parents had basic and secondary education. Most fathers were nonprofessional workers and most mothers were housewives. The majority of students belonged to the middle or low socioeconomic groups.

The overall prevalence of ADHD suspected by teachers in this student sample was $12.6 \%$ (Table 5). In univariate analysis, the risk of ADHD significantly decreased for girls and for children born to university graduate fathers and mothers. In contrast, the risk was significantly increased by living in rural areas; being born to fathers 


\begin{tabular}{|c|c|c|c|}
\hline Knowledge aspects about ADHD & $\begin{array}{l}\text { Pre-training } \\
\text { correct responses } \\
\quad n(\%)\end{array}$ & $\begin{array}{l}\text { Post-training } \\
\text { correct responses } \\
n(\%)\end{array}$ & $P$-value ${ }^{\text {a }}$ \\
\hline Nature of $A D H D$ & $11(28.2)$ & $34(87.2)$ & $<0.001$ \\
\hline Age of onset & $9(23.1)$ & $32(82.1)$ & $<0.001$ \\
\hline Sex prevalence & $18(46.2)$ & $28(71.8)$ & $<0.001$ \\
\hline Progress & $7(17.9)$ & $27(69.2)$ & $<0.001$ \\
\hline \multicolumn{4}{|l|}{ Symptoms } \\
\hline $\begin{array}{l}\text { Child is easily distracted } \\
\text { Child has trouble awaiting his/her turn } \\
\text { Does not seem to listen when spoken to directly } \\
\text { Often fidgets with hands or feet } \\
\text { Often talks excessively } \\
\text { Often gets up from seat when remaining in seat is expected } \\
\text { Often performs life-threatening acts }\end{array}$ & $\begin{array}{l}17(43.6) \\
16(41) \\
16(41) \\
18(46.2) \\
16(41) \\
14(35.9) \\
15(38.5)\end{array}$ & $\begin{array}{l}37(94.9) \\
37(94.9) \\
35(89.7) \\
37(94.9) \\
34(87.2) \\
35(89.7) \\
33(84.6)\end{array}$ & $<0.001$ \\
\hline \multicolumn{4}{|l|}{ Causes } \\
\hline $\begin{array}{l}\text { Family history } \\
\text { Head trauma } \\
\text { Home environment } \\
\text { Watching excess TV and video games }\end{array}$ & $\begin{array}{l}11(28.2) \\
11(28.2) \\
9(23.1) \\
11(28.2)\end{array}$ & $\begin{array}{l}33(84.6) \\
30(76.9) \\
24(61.5) \\
26(66.7)\end{array}$ & $<0.001$ \\
\hline \multicolumn{4}{|l|}{ Factors could increase the symptoms } \\
\hline $\begin{array}{l}\text { Watching excess TV and video games } \\
\text { Food that contain food additives and artificial colours } \\
\text { Family problems } \\
\text { Living with one parent }\end{array}$ & $\begin{array}{r}12(30.8) \\
11(28.2) \\
14(35.9) \\
11(28.2)\end{array}$ & $\begin{array}{l}36(92.3) \\
37(94.9) \\
37(94.9) \\
34(87.2)\end{array}$ & $<0.001$ \\
\hline Treatment lines & $10(25.6)$ & $34(87.2)$ & $<0.001$ \\
\hline
\end{tabular}

${ }^{a}$ McNemartest.

$A D H D=$ attention deficit hyperactivity disorder.

who were unemployed, clerks, manual workers, tradesmen and commercial workers; being born to mothers who were manual and commercial workers; belonging to low or middle socioeconomic groups; being in families with > 5 siblings; and being fed as an infant by mixed breast and artificial milk. The risk was not significantly associated with age, duration of pregnancy, mode and place of delivery, birth weight, birth order and living with one or both parents.

The independent predictors for nongenetic risk factors of ADHD as revealed by logistic regression analysis are presented in Table 6. The regression model explained only $20 \%$ of the possibility of ADHD. Girls were less likely to develop ADHD. Students of unemployed fathers were at the highest risk, followed by students from rural areas, students with fathers who were manual and commercial workers, and lastly,

\begin{tabular}{|c|c|c|c|c|c|c|}
\hline \multirow[t]{2}{*}{ Knowledge aspects } & \multirow{2}{*}{$\begin{array}{l}\text { Total item } \\
\text { score }\end{array}$} & \multicolumn{2}{|c|}{ Pre-training } & \multicolumn{2}{|c|}{ Post-training } & \multirow[t]{2}{*}{$P$-value ${ }^{a}$} \\
\hline & & Mean (SD) & $\begin{array}{l}\text { Median } \\
\text { (IQR) }\end{array}$ & Mean (SD) & $\begin{array}{l}\text { Median } \\
(\mathrm{IQR})\end{array}$ & \\
\hline $\begin{array}{l}\text { Nature, age of onset and sex } \\
\text { prevalence }\end{array}$ & 3 & $0.97(1.04)$ & $1(0-2)$ & $2.41(0.79)$ & $3(2-3)$ & $<0.001$ \\
\hline Causes & 4 & $1.08(1.63)$ & $0(0-2)$ & $2.90(1.17)$ & $3(2-4)$ & $<0.001$ \\
\hline Symptoms & 7 & $2.87(3.23)$ & $0(0-7)$ & $6.36(1.63)$ & $7(6-7)$ & $<0.001$ \\
\hline Factors which increase the symptoms & 4 & $1.23(1.72)$ & $0(0-3)$ & $3.69(0.92)$ & $4(3-4)$ & $<0.001$ \\
\hline Progress & 1 & $0.18(0.39)$ & $0(0)$ & $0.69(0.47)$ & $1(0-1)$ & $<0.001$ \\
\hline Treatment & 1 & $0.26(0.44)$ & $0(0-1)$ & $0.87(0.34)$ & $1(1)$ & $<0.001$ \\
\hline Total score & 20 & $8.26(6.28)$ & $3(0-12)$ & $16.92(4.09)$ & 18 (16-19) & $<0.001$ \\
\hline
\end{tabular}

${ }^{a}$ Wilcoxon rank test.

$A D H D=$ attention deficit hyperactivity disorder; $I Q R=$ interquartile range; $S D=$ standard deviation . 


\begin{tabular}{|c|c|c|c|c|}
\hline Sociodemographic characteristics & $\begin{array}{l}\text { Total } \\
n=39\end{array}$ & $\begin{array}{c}\text { Inadequate } \\
n(\%)\end{array}$ & $\begin{array}{c}\text { Adequate }^{b} \\
n(\%)\end{array}$ & $P$-value ${ }^{c}$ \\
\hline \multicolumn{5}{|l|}{ Age (years) } \\
\hline$<30$ & $3(7.7)$ & $1(33.3)$ & $2(66.7)$ & \multirow{3}{*}{0.09} \\
\hline $30-40$ & $20(51.3)$ & $13(65.0)$ & $7(35.0)$ & \\
\hline$\geq 41$ & $16(41.0)$ & $14(87.5)$ & $2(12.5)$ & \\
\hline \multicolumn{5}{|l|}{ Years of experience } \\
\hline $1-4$ & $3(7.7)$ & 0 & $3(100.0)$ & \multirow{3}{*}{0.022} \\
\hline $5-10$ & $8(20.5)$ & $6(75.0)$ & $2(25.0)$ & \\
\hline$>10$ & $28(71.8)$ & $22(78.6)$ & $6(21.4)$ & \\
\hline \multicolumn{5}{|l|}{ Sex } \\
\hline Male & $18(46.2)$ & $13(72.2)$ & $5(27.8)$ & \multirow{2}{*}{0.956} \\
\hline Female & $21(53.8)$ & $15(71.4)$ & $6(28.6)$ & \\
\hline \multicolumn{5}{|l|}{ School type } \\
\hline Urban & $26(66.7)$ & $18(69.2)$ & $8(30.8)$ & \multirow{3}{*}{0.88} \\
\hline Private & $7(17.9)$ & $5(71.4)$ & $2(28.6)$ & \\
\hline Rural & $6(15.4)$ & $5(83.3)$ & $1(16.7)$ & \\
\hline \multicolumn{5}{|l|}{ Educational level } \\
\hline Pre-university & $5(12.8)$ & $5(100.0)$ & 0 & \multirow{3}{*}{0.213} \\
\hline University & $30(76.9)$ & $21(70.0)$ & $9(30.0)$ & \\
\hline Postgraduate & $4(10.3)$ & $2(50.0)$ & $2(50.0)$ & \\
\hline
\end{tabular}

aInadequate knowledge refers to poor and fair score (< 65\%); badequate knowledge refers to good, very good and excellent scores (> 65\%); $\chi^{2}$ test. $A D H D=$ attention deficit hyperactivity disorder;

students who had mixed breast and bottle feeding as an infant.

\section{Discussion}

Analysis of the role of primary school teachers in early identification of ADHD among young schoolchildren revealed a large knowledge gap in different aspects of ADHD, with scores ranging from 17.9 to $46.2 \%$. These were lower than in a study from Southern Texas with scores ranging from 46 to 66\% (16).

Although the teachers' knowledge about some symptoms of ADHD was high, their knowledge about the nature, causes, consequences and methods of treatment of ADHD was low. These results concur with the study of Sciutto and associates who reported that scores for symptoms and diagnosis were significantly greater than scores for treatment and general information (17). This poor knowledge may contribute to delayed detection of ADHD and improper management of the associated learning and behavioural problems (17).

We found that the teachers' knowledge and perception about $\mathrm{ADHD}$ was mostly acquired from television, followed by magazines and books. This finding is in line with a survey of elementary school teachers' knowledge and attitudes towards ADHD in Turkey, which found that the main sources of knowledge were television, friends and newspapers, and not formal training (18).

In the current study, being newly graduated was the only factor that positively affected the level of pre-training knowledge of ADHD. This may reflect the recently improved teaching curricula that pay more attention to ADHD. It is reported that teachers' participation in formal training targeted at $\mathrm{ADHD}$ is positively correlated with increased knowledge of ADHD and acceptability of behaviour management strategies
(9). These findings highlight the fact that higher education institutions and school education directorates have not been successful in preparing school teachers for dealing with students with special needs including ADHD students.

The present study indicated that an ADHD training workshop was effective in increasing teachers' knowledge of ADHD. This is consistent with a previous study that reported the effectiveness of a workshop and in-service training programme for improving teachers' knowledge of ADHD (12).

In the present study, the overall prevalence of ADHD suspected by teachers was $12.6 \%$. This was higher than the 6\% reported by a study in Egypt (19). Among Arab countries, the prevalence of ADHD detected in the present study was higher than that obtained by a cross-sectional study in Qatar (9.4\%) and Oman $(5.1 \%$ in girls and $7.8 \%$ in boys) but lower than in the United Arab Emirates (14.9\%) (20) and Saudi 


\begin{tabular}{|c|c|}
\hline \multicolumn{2}{|c|}{$\begin{array}{l}\text { Table } 4 \text { Sociodemographic characteristics of the studied primary school children } \\
(n=873)\end{array}$} \\
\hline Sociodemographic criteria & No. $(\%)$ \\
\hline \multicolumn{2}{|l|}{ Age (years) } \\
\hline 7- & $299(34.25)$ \\
\hline 9- & $354(40.55)$ \\
\hline$\geq 11$ & $220(25.20)$ \\
\hline \multicolumn{2}{|l|}{ Gender } \\
\hline Boys & $428(49.03)$ \\
\hline Girls & $445(50.97)$ \\
\hline \multicolumn{2}{|l|}{ Residence } \\
\hline Urban & $636(72.85)$ \\
\hline Rural & $237(27.15)$ \\
\hline \multicolumn{2}{|l|}{ Fathers'education } \\
\hline Illiterate & $134(15.30)$ \\
\hline Basic and secondary education & $400(45.80)$ \\
\hline University graduate and postgraduate & $339(38.80)$ \\
\hline \multicolumn{2}{|l|}{ Mothers'education } \\
\hline Illiterate & $109(12.50)$ \\
\hline Basic and secondary education & $446(51.10)$ \\
\hline University graduate and postgraduate & $318(36.40)$ \\
\hline \multicolumn{2}{|l|}{ Fathers'occupation } \\
\hline Professional and semiprofessional & $265(30.40)$ \\
\hline Clerk & $146(16.70)$ \\
\hline Manual workera, trade business and commerce & $454(52.0)$ \\
\hline Unemployed & $8(0.90)$ \\
\hline \multicolumn{2}{|l|}{ Mothers'occupation } \\
\hline Professional and semiprofessional & $118(13.50)$ \\
\hline Clerk & $68(7.80)$ \\
\hline Manual workera, trade business and commerce & $22(2.50)$ \\
\hline Housewife & $665(76.20)$ \\
\hline \multicolumn{2}{|l|}{ Socioeconomic status } \\
\hline High & $413(47.31)$ \\
\hline Middle & $263(30.13)$ \\
\hline Low & $197(22.56)$ \\
\hline
\end{tabular}

${ }^{a}$ Nonprofessional occupations.

Arabia (16.4\%) (21). Worldwide, the prevalence in the current study was lower than in India (15.5\%) (22), and the United States of America (USA) (19.0\%) (23) but higher than in Canada (9.0\%) and New Zealand (5.0\%) (24). This variability in the prevalence of ADHD could be attributed to variation in the demography of the study populations, study design and criteria for selecting key symptoms (e.g., inattention, impulsivity and hyperactivity).
In the present study, there was a higher prevalence rate of ADHD among boys (15.2\%) than girls (10.1\%), and the male to female ratio was $1.5: 1$. This was similar to a previous study that reported a high male to female ratio (25). The sex difference is difficult to explain, because most of the aetiopathogenesis and acquired risk factors reported in the pre-, peri- and postnatal periods (first 2 years) do not differ between the sexes. However, one possible explanation is that the larger head and skeletal immaturity of male relative to female infants renders boys more susceptible to pressure and head injury at birth, which may predispose to later development of ADHD. Also, it could be attributed to genetic variations (26).

In this study, low socioeconomic status was a significant risk factor for ADHD. This agrees with previous studies in Egypt (13) and the USA (27). There are two potential explanations for this association. First is a true effect whereby children in lower socioeconomic groups truly have higher levels of $\mathrm{ADHD}$ symptoms. The second is a false effect due to difference in awareness, access to health and reporting between groups (27).

The present study showed a significant association between low parental education level and ADHD. This may be because such parents have poor knowledge of how to care children with ADHD. They may also lack relevant parenting skills and might treat children with $\mathrm{ADHD}$ violently and aggressively, which may lead to increased symptoms of ADHD. In contrast, if parents have received higher education, it has a positive effect on the physical and psychological health of children with ADHD (28).

The current study showed that belonging to families with parents in professional and semiprofessional jobs minimized the risk of ADHD, which may be explained by the associated high level of education and socioeconomic status. The lower prevalence of ADHD among children born to housewives compared to clerks and manual workers is consistent with the suggestion that housewives are in a better position to look after their children at home, both socially and psychologically. The high risk of ADHD in families without a working father could be explained by the impact of unemployment on socioeconomic instability and the associated physical and psychological problems in children (27). 


\begin{tabular}{|c|c|c|c|}
\hline Predictors & Total & ADHD n (\%) & OR $(95 \% \mathrm{Cl}) \mathrm{a}$ \\
\hline Prevalence of $A D H D$ & 873 & $110(12.6)$ & \\
\hline \multicolumn{4}{|l|}{ Age (years) } \\
\hline-7 & 299 & $32(10.70)$ & Ref \\
\hline-9 & 354 & $56(15.80)$ & $1.57(0.99-2.50)$ \\
\hline$\geq 11$ & 220 & $22(10.0)$ & $0.93(0.52-1.64)$ \\
\hline \multicolumn{4}{|l|}{ Gender } \\
\hline Boys & 428 & $65(15.20)$ & Ref \\
\hline $\begin{array}{c}\text { Girls } \\
\text { Residence }\end{array}$ & 445 & $45(10.10)$ & $0.63(0.42-0.94)$ \\
\hline Urban & 636 & $43(6.80)$ & Ref \\
\hline Rural & 237 & $67(28.30)$ & $5.44(3.57-8.27)$ \\
\hline \multicolumn{4}{|l|}{ Fathers' education } \\
\hline Illiterate & 134 & $27(20.10)$ & Ref \\
\hline Basic and secondary education & 400 & $59(14.80)$ & $0.69(0.41-1.14)$ \\
\hline University graduate and postgraduate & 339 & $24(7.10)$ & $0.30(0.17-0.55)$ \\
\hline \multicolumn{4}{|l|}{ Mothers'education } \\
\hline Illiterate & 109 & $20(18.30)$ & Ref \\
\hline Basic and secondary education & 446 & $65(14.60)$ & $0.76(0.44-1.32)$ \\
\hline University graduate and postgraduate & 318 & $25(7.90)$ & $0.02(0.01-0.04)$ \\
\hline \multicolumn{4}{|l|}{ Fathers'occupation } \\
\hline Professional and semiprofessional & 265 & $13(4.90)$ & Ref \\
\hline Clerk & 146 & $21(14.40)$ & $3.26(1.58-6.72)$ \\
\hline Manual worker, trade business and commerce & 454 & $72(15.90)$ & $3.65(1.98-6.74)$ \\
\hline Unemployed & 8 & $4(50.0)$ & $19.38(4.35-86.34)$ \\
\hline \multicolumn{4}{|l|}{ Mothers'occupation } \\
\hline Professional and semiprofessional & 118 & $9(7.60)$ & Ref \\
\hline Clerk & 68 & $11(16.20)$ & $2.34(0.92-5.79)$ \\
\hline Manual worker, trade business and commerce & 22 & $8(36.40)$ & $6.92(2.30-20.85)$ \\
\hline Housewife & 665 & $82(12.30)$ & $1.72(0.84-3.52)$ \\
\hline \multicolumn{4}{|l|}{ Socioeconomic status } \\
\hline High & 413 & $32(7.70)$ & Ref \\
\hline Middle & 263 & $39(14.80)$ & $2.07(1.26-3.40)$ \\
\hline Low & 197 & $39(19.80)$ & $2.94(1.78-4.86)$ \\
\hline \multicolumn{4}{|l|}{ Birth order } \\
\hline 1st & 325 & $43(13.20)$ & Ref \\
\hline 2nd & 284 & $34(12.0)$ & $0.89(0.55-1.44)$ \\
\hline $3 r d$ & 179 & $24(13.40)$ & $1.02(0.59-1.74)$ \\
\hline 4 th & 61 & $5(8.20)$ & $0.59(0.22-1.54)$ \\
\hline 5th and more & 24 & $4(44.40)$ & $1.32(0.43-4.05)$ \\
\hline \multicolumn{4}{|l|}{ Living with both parents or single parent } \\
\hline Both parents & 822 & $101(12.30)$ & Ref \\
\hline Single parent & 51 & $9(17.60)$ & $1.53(0.72-3.24)$ \\
\hline \multicolumn{4}{|l|}{ No. of siblings } \\
\hline $0-4$ & 803 & $95(11.80)$ & Ref \\
\hline $5-8$ & 77 & $15(21.40)$ & $2.02(1.01-3.72)$ \\
\hline \multicolumn{4}{|l|}{ Duration of pregnancy } \\
\hline Full term & 835 & $102(12.20)$ & Ref \\
\hline Preterm & 38 & $8(21.10)$ & $1.92(0.86-4.29)$ \\
\hline \multicolumn{4}{|l|}{ Mode of delivery } \\
\hline Vaginal & 600 & $75(12.50)$ & Ref \\
\hline Caesarean section & 273 & $35(12.80)$ & $1.03(0.67-1.58)$ \\
\hline \multicolumn{4}{|l|}{ Place of delivery } \\
\hline Hospital & 831 & $105(12.60)$ & Ref \\
\hline Home & 42 & $5(11.90)$ & $0.93(0.36-2.43)$ \\
\hline
\end{tabular}




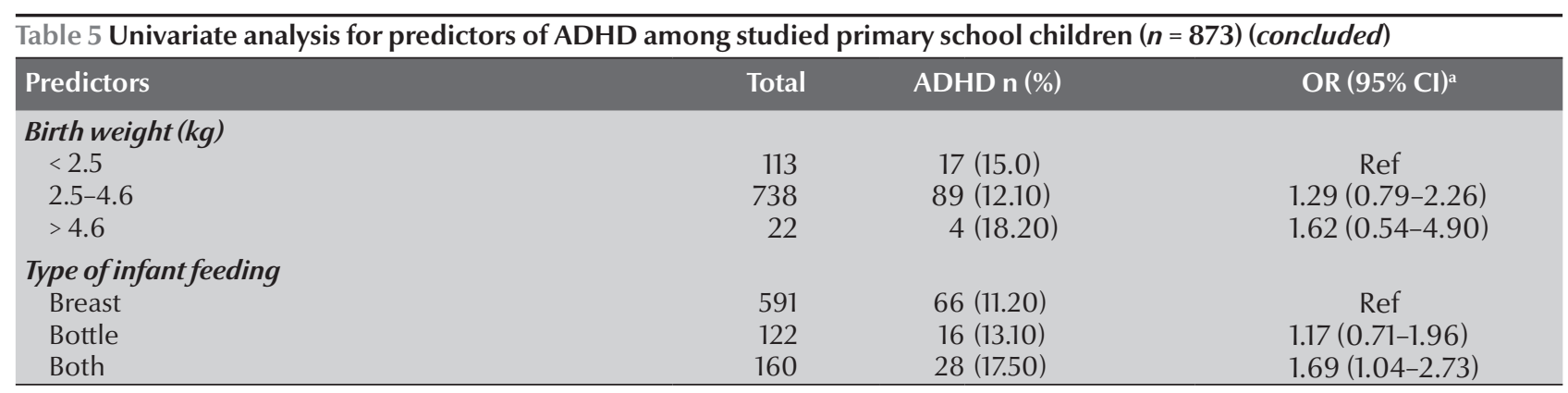

a Bivariate analysis.

$A D H D=$ attention deficit hyperactivity disorder; $C I=$ confidence interval; OR = odds ratio; $R e f=$ reference group

\begin{tabular}{|c|c|c|c|c|}
\hline Predictor & $\beta$ & SE & $P$-value & OR $(95 \% \mathrm{CI})^{\mathrm{a}}$ \\
\hline \multicolumn{5}{|l|}{ Gender } \\
\hline Boys & - & - & - & Ref \\
\hline Girls & 0.57 & 0.22 & 0.009 & $0.56(0.37-0.87)$ \\
\hline \multicolumn{5}{|l|}{ Residence } \\
\hline Urban & - & - & - & Ref \\
\hline Rural & 1.69 & 0.23 & $<0.001$ & $4.57(2.94-7.10)$ \\
\hline \multicolumn{5}{|l|}{ Fathers'education } \\
\hline Illiterate & - & - & - & Ref \\
\hline Basic and secondary education & -0.06 & 0.40 & 0.89 & $0.94(0.53-2.48)$ \\
\hline University graduate and postgraduate & -0.17 & 0.56 & 0.75 & $0.83(0.28-2.52)$ \\
\hline \multicolumn{5}{|l|}{ Mothers'education } \\
\hline Illiterate & - & - & - & Ref \\
\hline Basic and secondary education & -0.08 & 0.46 & 0.55 & $0.90(0.59-2.34)$ \\
\hline University graduate and postgraduate & -0.11 & 0.43 & 0.44 & $0.85(0.54-2.13)$ \\
\hline \multicolumn{5}{|l|}{ Fathers'occupation } \\
\hline Professional and semiprofessional & - & - & - & Ref \\
\hline Clerk & 0.77 & 0.49 & 0.045 & $2.06(0.97-4.39)$ \\
\hline Manual worker, trade business and commerce & 0.89 & 0.41 & 0.007 & $2.38(1.26-4.51)$ \\
\hline Unemployed & 2.29 & 0.89 & 0.005 & $9.10(1.84-45.05)$ \\
\hline \multicolumn{5}{|l|}{ Mothers'occupation } \\
\hline Professional and semiprofessional & - & - & - & Ref \\
\hline Clerk & -0.21 & 0.53 & 0.70 & $0.80(0.28-2.34)$ \\
\hline Manual worker, trade business and commerce & 1.10 & 0.71 & 0.13 & $3.02(0.73-12.46)$ \\
\hline Housewife & 0.14 & 1.12 & 0.91 & $1.14(0.14-13.15)$ \\
\hline \multicolumn{5}{|l|}{ Socioeconomic status } \\
\hline High & - & - & - & Ref \\
\hline Middle & 0.07 & 0.34 & 0.83 & $1.079(0.54-2.12)$ \\
\hline Low & 0.38 & 0.27 & 0.70 & $1.461(0.21-9.99)$ \\
\hline \multicolumn{5}{|l|}{ No. of siblings } \\
\hline $0-4$ & - & - & - & Ref \\
\hline $5-8$ & 0.53 & 0.36 & 0.14 & $1.70(0.83-3.47)$ \\
\hline \multicolumn{5}{|l|}{ Type of infant feeding } \\
\hline Breast & - & - & - & Ref \\
\hline Bottle & 0.28 & 0.32 & 0.39 & $1.32(0.7-2.48)$ \\
\hline Both & 0.57 & 0.27 & 0.04 & $1.78(1.03-3.06)$ \\
\hline Constant, Model $\chi^{2}$ and $P$ value & - & - & $-3.69,98.27, \leq 0.001$ & - \\
\hline Correctly predicted (\%) & - & - & 20.2 & - \\
\hline
\end{tabular}

${ }^{a}$ Multiple logistic regression

$A D H D=$ attention deficit hyperactivity disorder; $O R=$ odds ratio; $C I=$ confidence interval $;$ Ref = reference group; $S E=$ standard error . 
We observed that the risk of ADHD was significantly higher in rural compared with urban areas. There is controversy about the effect of rural and urban communities on the development of ADHD. This inconsistency might result from differences in the definition of rural and urban communities among studies, as well as differences in the nature of the rural and urban areas themselves (28).

In the present study, the risk of ADHD was higher in children from large families, which has been shown previously (29). Also, the risk of ADHD was higher among children living with a single parent, although not significantly. Parental separation and divorce have been shown to have negative impacts on kids behaviour, such as inconsistent parenting and more punishment, aggression and criticism (30).

In the present study, the type of infant feeding, duration of pregnancy, mode and place of delivery and low birth weight were not associated with ADHD. These findings were consistent with a previous study that showed that pregnancy and labour characteristics were not associated with ADHD (31). In the present study, mixed artificial and breast feeding was a significant risk factor for ADHD. This could be attributed to depriving the child of warmth and contact with the mother's breast during feeding. Also, no significant association was found between ADHD and birth order. This is in line with a study that found equal risk of $\mathrm{ADHD}$ in different birth orders (32).

In the current study, the nongenetic risk factors for ADHD by logistic regression analysis explained only $20 \%$ of the possibility of ADHD. This supports the hypothesis that the aetiology of ADHD is multifactorial with a strong genetic component (5).

The present study had several limitations. The study addressed the problem of ADHD in primary school children and the role of teachers in Mansoura District only. A larger national study should be conducted with a representative sample to address such an important problem among children throughout Egypt. Furthermore, the current study evaluated the impact of educational programmes in improving the knowledge of teachers regarding detection and care of children with ADHD. Another interventional study is recommended to evaluate and improve the practice of teachers in management of ADHD.

In conclusion, this study highlights an important issue for the health and welfare of primary school children in Egypt: the high prevalence of ADHD and the knowledge gap in teachers for detection of different aspects of ADHD. The public health and education authorities should continue their efforts to raise awareness among parents, teachers and healthcare workers about the methods of ADHD detection and management to improve children's quality of life and learning capabilities. Also, steps should be taken to improve the educational process and control the detected modifiable risk factors such as unemployment, low educational level, low socioeconomic status and large family size. Improving the ability of school teachers to assess and care for students with special needs including ADHD, especially in primary education, could be key to improving student health and academic achievement.

\section{Funding: None.}

Conflict of interest: None declared.

\section{References}

1. Purper-Ouakil D, Wohl M, Michel G, Mouren MC, Gorwood P. Variations dans l'expression clinique du trouble déficit attentionnel/hyperactivité (TDAH): rôle du contexte, du développement et de la comorbidité thymique [Symptom variations in attention deficit/hyperactivity disorder: importance of context, development and comorbidity]. Encephale. 2004 Nov-Dec;30(6):533-9. (in French) PMID:15738855

2. Birchwood J, Daley D. Brief report: the impact of attention deficit hyperactivity disorder (ADHD) symptoms on academic performance in an adolescent community sample. J Adolesc. 2012 Feb;35(1):225-31. PMID:20880572

3. Busch B, Biederman J, Cohen LG, Sayer JM, Monuteaux MC, Mick E, et al. Correlates of ADHD among children in pediatric and psychiatric clinics. Psychiatr Serv. 2002 Sep;53(9):1103-11. PMID:12221308

4. Fredriksen M, Dahl AA, Martinsen EW, Klungsoyr O, Faraone SV, Peleikis DE. Childhood and persistent ADHD symptoms associated with educational failure and long-term occupational disability in adult ADHD. Atten Defic Hyperact Disord. 2014 Jun;6(2):87-99. PMID:24497125

5. Sagiv SK, Epstein JN, Bellinger DC, Korrick SA. Pre- and postnatal risk factors for $A D H D$ in a nonclinical pediatric population. J Atten Disord. 2013 Jan;17(1):47-57. PMID:22298092
6. Pelham WE, Foster EM, Robb JA. The economic impact of attention-deficit/hyperactivity disorder in children and adolescents. Ambul Pediatr. 2007 Jan-Feb;7(1 Suppl):121-31. PMID:17261491

7. Wolraich ML, Lambert EW, Bickman L, Simmons T, Doffing MA, Worley KA. Assessing the impact of parent and teacher agreement on diagnosing attention-deficit hyperactivity disorder. J Dev Behav Pediatr. 2004 Feb;25(1):41-7. PMID:14767355

8. Honkala S. World Health Organization approaches for surveys of health behaviour among schoolchildren and for healthpromoting schools. Med Princ Pract. 2014;23 Suppl 1:24-31. PMID:23949020

9. Nur N, Kavakci O. Elementary school teachers' knowledge and attitudes related to attention deficit hyperactivity disorder. Health Med. 2010 Jun;4(2):350-5.

10. Lwanga SK, Lemeshow S. Sample size determination in health studies: a practical manual. Geneva: World Health Organization; 1991 (http://apps.who.int/iris/bitstream/10665/40062/1/9241544058_(p1-p22).pdf, accessed 7 September 2016).

11. Kos J. Primary school teachers' knowledge, attitudes and behaviours toward children with attention-deficit/hyperactivity 
disorder. 2004. http://www.works.bepress.com/julie_kos/9., accessed 2 July 2014))

12. Attia M, Tayel K, Mounier G, Ahmed M, Abo-Rass N. ADHD: Part I prevalence and some socio-demographic parameters. Alex J Pediatrics. 2000;14:1-8.

13. Fahmy S, El-Sherbini A. Determining simple parameters for social classifications for health research. Bull High Inst Public Health. 1983;13(5):95-108.

14. Hassan AM, Al-Haidar F, Al-Alim F, Al-Hag O. A screening tool for attention deficit hyperactivity disorder in children in Saudi Arabia. Ann Saudi Med. 2009 Jul-Aug;29(4):294. PMID:19584573

15. DuPaul GJ, Power TJ, Anastopoulos AD, Reid R. ADHD Rating Scale-IV: checklists, norms, and clinical interpretation: New York: Guilford Press; 1998.

16. Guerra FR Jr, Brown MS. Teacher knowledge of attention deficit hyperactivity disorder among middle school students in South Texas. RMLE Online. 2012;36(3):1-7.

17. Sciutto MJ. ADHD knowledge, misconceptions, and treatment acceptability. J Atten Disord. 2015;19(2):91-8. PMID:23893531

18. Holz T, Lessing A. Reflections on attention deficit hyperactivity disorder (ADHD) in an inclusive education system: research paper. Perspect Educ. 2002;20(3):103-10.

19. El-Tallawy HN, Hassan WA, El-Behary A, Shehata GA. Prevalence of attention deficit hyperactivity disorder among elementary schools children in Assiut City-Egypt. Egypt J Neurol Psychiatry Neurosurg. 2005;42(2):517-26.

20. Bu-Haroon A, Eapen V, Bener A. The prevalence of hyperactivity symptoms in the United Arab Emirates. Nord J Psychiatry. 1999;53(6):439-42.

21. Al Hamed JH, Taha AZ, Sabra AA, Bella H. Attention deficit hyperactivity disorder (ADHD) among male primary school children in Dammam, Saudi Arabia: prevalence and associated factors. J Egypt Public Health Assoc. 2008;83(3-4):165-82. PMID:19302773

22. Mukhopadhyay M, Misra S, Mitra T, Niyogi P. Attention deficit hyperactivity disorder. Indian J Pediatr. 2003 Oct;70(10):78992. PMID:14649473
23. Faraone SV, Sergeant J, Gillberg C, Biederman J. The worldwide prevalence of ADHD: is it an American condition? World Psychiatry. 2003 Jun;2(2):104-13. PMID:16946911

24. Wolraich ML, Wibelsman CJ, Brown TE, Evans SW, Gotlieb EM, Knight JR, et al. Attention deficit/hyperactivity disorder among adolescents: a review of the diagnosis, treatment and clinical implications. Pediatrics. 2005 Jun;115:1734-46. PMID:15930238

25. Fayyad J, De Graaf R, Kessler R, Alonso J, Angermeyer M, Demyttenaere K, et al. Cross-national prevalence and correlates of adult attention-deficit hyperactivity disorder. Br J Psychiatry. 2007 May;190(5):402-9. PMID:17470954

26. Tannock R. Attention deficit hyperactivity disorder: advances in cognitive, neurobiological, and genetic research. J Child Psychol Psychiatry. 1998 Jan;39(1):65-99. PMID:9534087

27. Russell G, Ford T, Rosenberg R, Kelly S. The association of attention deficit hyperactivity disorder with socioeconomic disadvantage: alternative explanations and evidence. J Child Psychol Psychiatry. 2014 May;55(5):436-45. PMID:24274762

28. Boyle CA, Boulet S, Schieve LA, Cohen RA, Blumberg SJ, Yeargin-Allsopp M, et al. Trends in the prevalence of developmental disabilities in US children, 1997-2008. Pediatrics. 2011 Jun;127(6):1034-42. PMID:21606152

29. Bella H. Attention deficit hyperactivity disorder (ADHD): Is it a health problem among male primary school children. Bahrain Med Bull. 2008;30(2):67-71

30. Peen J, Schoevers RA, Beekman AT, Dekker J. The current status of urban-rural differences in psychiatric disorders. Acta Psychiatr Scand. 2010 Feb;121(2):84-93. PMID:19624573

31. Andrés M, Catala M, Gómez-Beneyto M. Prevalence, comorbidity, risk factors and service utilisation of disruptive behaviour disorders in a community sample of children in Valencia (Spain). Soc Psychiatry Psychiatr Epidemiol. 1999 Apr;34(4):175-9. PMID:10365622

32. Counts CA, Nigg JT, Stawicki JA, Rappley MD, Von Eye A. Family adversity in DSM-IV ADHD combined and inattentive subtypes and associated disruptive behavior problems. J Am Acad Child Adolesc Psychiatry. 2005 Jul;44(7):690-8. PMID:15968238 